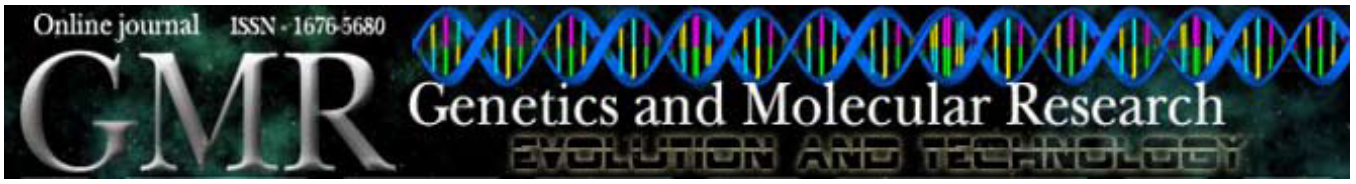

\title{
Mutagenicity of the Musa paradisiaca (Musaceae) fruit peel extract in mouse peripheral blood cells in vivo
}

\author{
C.U.B. Andrade ${ }^{1}$, F.F. Perazzo ${ }^{2}$ and E.L. Maistro ${ }^{3}$ \\ ${ }^{1}$ Faculdade de Enfermagem, UNIFENAS, Alfenas, MG, Brasil \\ ${ }^{2}$ Laboratório de Fármacos, Universidade Federal do Amapá, Macapá, PA, Brasil \\ ${ }^{3}$ Departamento de Fonoaudiologia, Universidade Estadual Paulista, \\ Faculdade de Filosofia e Ciências, Marília, SP, Brasil \\ Corresponding author: E.L. Maistro \\ E-mail: edson.maistro@marilia.unesp.br
}

Genet. Mol. Res. 7 (3): 725-732 (2008)

Received March 19, 2008

Accepted July 2, 2008

Published August 14, 2008

\begin{abstract}
Plants are a source of many biologically active products and nowadays they are of great interest to the pharmaceutical industry. In the present study, the mutagenic potential of the Musa paradisiaca fruit peel extract was assessed by the single-cell gel electrophoresis (SCGE) and micronucleus assays. Animals were treated orally with three different concentrations of the extract $(1000,1500$, and $2000 \mathrm{mg} / \mathrm{kg}$ body weight). Peripheral blood cells of Swiss mice were collected $24 \mathrm{~h}$ after treatment for the SCGE assay and 48 and $72 \mathrm{~h}$ for the micronucleus test. The results showed that the two higher doses of the extract of $M$. paradisiaca induced statistically significant increases in the average numbers of DNA damage in peripheral blood leukocytes for the two higher doses and a significant increase in the mean of micronucleated polychromatic erythrocytes in the three doses tested. The polychromatic/ normochromatic erythrocyte ratio scored in the treated groups was not statistically different from the negative control. The data obtained indicate that fruit peel extract from M. paradisiaca showed mutagenic effect in the peripheral blood cells of Swiss albino mice.
\end{abstract}

Key words: Musa paradisiaca; Single-cell gel electrophoresis; Micronucleus test; Peripheral blood cells; Comet assay 


\section{INTRODUCTION}

Since the beginning of civilization, people have used plants as medicine, because they are an important source of many biologically active products. Recently, there has been evidence of a growing interest in plants as a significant source of new pharmaceuticals. Many of today's drugs have been derived from plants, for example, digoxin from Digitalis spp, quinine and quinidine from Chinchona spp, vincristine and vinblastine from Catharanthus roseus, atropine from Atropa belladonna, morphine and codeine from Papaver somniferum (Rates, 2001). The medical and economical importance of plants has motivated several ethnopharmacological studies that have resulted in the discovery of many interesting properties of plants. Generally, these properties are based on the studies of how native people use plants therapeutically (Barrett, 1994; Coe and Anderson, 1999). Different communities and cultures often use the same plant in different ways. Therefore, it is important to investigate the use and the risks that these products may pose to health.

Musa paradisiaca L. (Musaceae), popularly known as "banana", is a perennial treelike herb widely distributed in moist tropics. Due to the enriched food value and versatile medicinal value, banana is one of the most important fruits and vegetable crops of several countries. Fruits, leaves, peels, root, and stalks from banana plants have been used orally or topically as a medicine for treating diarrhoea and dysentery, in the healing of intestinal lesions in colitis (Stover and Simmonds, 1987), antilithic (Prasad et al., 1993), inflammation, pains and snakebite (Coe and Anderson, 1999), antiulcerogenic activity (Lewis et al., 1999; Goel et al., 2001), hypoglycemic effect (Ojewole and Adewunmi, 2003), and hypolipidemic and antioxidant actions (Krishnan and Vijayalakshmi, 2005). A constituent hydroxyanigorufone obtained from M. paradisiaca showed to be a potential cancer chemopreventive agent (Jang et al., 2002), and Houghton and Skari (1992) and Borges et al. (2005) have also reported the antivenom action of the stem juice from banana plant. Processes for the production of paper pulp, biogas, alcoholic beverages, etc., from banana plant have also been described (Tewari et al., 1986). In this report, we determined the mutagenic response of the M. paradisiaca fruit peel extract by measuring DNA damage by the single-cell gel electrophoresis (SCGE) assay and the mean number of micronucleated cells by the micronucleus test on peripheral blood cells from mice in vivo.

\section{MATERIAL AND METHODS}

\section{Plant material}

Fresh peels (500 g) of Musa paradisiaca (banana) were air dried at $40^{\circ} \mathrm{C}$, powdered and extracted by maceration with water-ethanolic solution (4.0:1, 70.0\%) for 2 days. The macerate was filtered, and the extraction procedure repeated. The concentration of the combined extracts under reduced pressure furnished $68.27 \mathrm{~g}$ (yield 13.65\%) of crude water-ethanolic extract.

\section{Chemicals}

N-nitroso-N-ethylurea (ENU, CAS No. 759-73-9) was used as the DNA-damaging 
agent detected by SCGE and micronucleus assays. ENU was dissolved in phosphate buffer, $\mathrm{pH}$ 6. The other main chemicals used were obtained from the following suppliers: normal melting point agarose (cat. No. 15510-019; Invitrogen); low melting point agarose (cat. No. 15517-014; Invitrogen); sodium salt $N$-lauroyl sarcosine (L-5125; Sigma) and ethylenediaminetetraacetic acid (EDTA; Merck).

\section{Animals and assay procedures}

Experiments were carried out in 12-week-old Swiss mice (Mus musculus), weighing 25-30 g. The animals were acquired from the animal house of the Jose do Rosario Vellano University (UNIFENAS), kept in polyethylene boxes $(\mathrm{N}=6)$, in a climate-controlled environment $\left(25 \pm 4^{\circ} \mathrm{C}, 55 \pm 5 \%\right.$ humidity) with a 12-h light/dark cycle (7:00 am to 7:00 $\mathrm{pm})$. Food (Labina-Purina) and water were available ad libitum. Mice were divided into 5 experimental groups of six animals each (three females and three males). Musa paradisiaca extract was administered in a single dose of $0.5 \mathrm{~mL}$, by gavage, at concentrations of 1000,1500 , and $2000 \mathrm{mg} / \mathrm{kg}$ body weight, chosen on the basis of our acute toxicity studies in mice, which was higher than $2000 \mathrm{mg} / \mathrm{kg}$. The negative control group received distilled water. The positive control group received $50 \mathrm{mg}$ ENU/ $\mathrm{kg}$. The SCGE test was carried out according to the method described by Speit and Hartmann (1999), which was based on the original study of Singh et al. (1988) and included modifications introduced by Klaude et al. (1996) as well as additional modifications. Twenty-four hours after the treatment, peripheral blood leukocytes were examined. A $10-\mu \mathrm{L}$ aliquot of the blood cells from each animal was mixed with $120 \mu \mathrm{L} 0.5 \%$ low melting point agarose at $37^{\circ} \mathrm{C}$, and rapidly spread onto microscope slides pre-coated with $1.5 \%$ normal melting point agarose. Coverslips were added and the slides were allowed to gel at $4^{\circ} \mathrm{C}$ for $20 \mathrm{~min}$. The coverslips were removed gently and the slides were then immersed in cold, freshly prepared lysing solution consisting of $89 \mathrm{~mL}$ of a stock solution $(2.5 \mathrm{M} \mathrm{NaCl}, 100 \mathrm{mM}$ EDTA, $10 \mathrm{mM}$ Tris, $\mathrm{pH}$ set to 10.0 with $\sim 8 \mathrm{~g}$ solid $\mathrm{NaOH}, 890 \mathrm{~mL}$ distilled water and $1 \%$ sodium lauryl sarcosine), plus $1 \mathrm{~mL}$ Triton X-100 (Merck) and $10 \mathrm{~mL}$ DMSO. After protecting from light, the slides were left to stand at $4^{\circ} \mathrm{C}$ for $1 \mathrm{~h}$ and then placed in the gel box, positioned at the anode end, and left in a high $\mathrm{pH}(>13)$ electrophoresis buffer $(300 \mathrm{mM} \mathrm{NaOH}$ per 1 mM EDTA, prepared from a stock solution of $10 \mathrm{~N} \mathrm{NaOH}$ and 200 mM EDTA, pH 10.0) at $4{ }^{\circ} \mathrm{C}$ for $20 \mathrm{~min}$ before electrophoresis to allow the DNA to unwind. The electrophoresis run was performed in an ice bath $\left(4^{\circ} \mathrm{C}\right)$ for $20 \mathrm{~min}$ at $25 \mathrm{~V}$ and $300 \mathrm{~mA}$. The slides were then submerged in a neutralized buffer $(0.4 \mathrm{M}$ Tris- $\mathrm{HCl}, \mathrm{pH} 7.5)$ for $15 \mathrm{~min}$, dried at room temperature and fixed in $100 \%$ ethyl alcohol for $10 \mathrm{~min}$. The slides were dried and stored at least overnight before staining. For the process of staining, slides were briefly rinsed in distilled water, covered with $30 \mu \mathrm{L} 1 \mathrm{X}$ ethidium bromide-staining solution prepared from a 10X stock $(200 \mu \mathrm{g} / \mathrm{mL})$ and covered with a coverslip. The material was evaluated immediately at a 400X magnification, using a fluorescence microscope (Nikon) with a 515-560-nm excitation filter and a 590-nm barrier filter. For the micronucleus assay, peripheral blood from the same animals used in the SCGE procedure was collected from an orbital vein, 48 and $72 \mathrm{~h}$ after the treatment and then slides of blood smears were made. All slides were coded, fixed with methanol and stained with Giemsa solution. For the micronucleus assay, 4000 polychromatic erythrocytes were scored from each Swiss mouse 
(2000 cells from the 48-h blood sample and 2000 cells from the 72-h blood sample). One thousand cells were analyzed per animal to determine the polychromatic/normochromatic erythrocyte ratio. All animals were submitted to euthanasia after the 72-h blood sample collection. The Animal Bioethical Committee of the UNIFENAS, Brazil, approved the present study on September 28, 2005 (protocol No. 13A/2005), in accordance with the Federal Government legislation on animal care.

\section{Scoring procedures and data evaluation}

The extent and distribution of DNA damage indicated by the SCGE assay were evaluated by examining at least 100 randomly selected and non-overlapping cells on the slides of each animal. These cells were scored visually according to tail size into four classes, as follow: i) class 0 : undamaged, with no tail; ii) class 1: with a tail shorter than the diameter of the head (nucleus); iii) class 2: with a tail length 1 to 2 times the diameter of the head, and iv) class 3: with a tail longer than 2 times the diameter of the head. Comets with no heads and images with nearly all DNA in the tail, or with a very wide tail, were excluded from evaluation because they probably represented dead cells (Hartmann and Speit, 1997). The total score for 100 comets was obtained by multiplying the number of cells in each class by the damage class, ranging from 0 (all undamaged) to 300 (all maximally damaged).

\section{Statistical analysis}

Micronucleus and SCGE assay data were submitted to one-way analysis of variance (ANOVA) and the Tukey-Kramer multiple comparison test (Sokal and Rohlf, 1995), using the GraphPad Instat ${ }^{\mathbb{}}$ software, version 3.01. Results were considered to be statistically significant at $\mathrm{P}<0.05$.

\section{RESULTS AND DISCUSSION}

The alkaline SCGE (Comet) assay is a rapid and sensitive procedure for quantifying DNA damage in mammalian cells (Singh et al., 1988; Sasaki et al., 1997). In this assay, relaxed and broken DNA fragments stream further from the nucleus than intact DNA, so the extent of DNA damage can be measured by the length of the stream. Furthermore, DNA lesions can be measured by the absence of mitotic activity.

Table 1 shows the effects of a 24-h treatment with the $M$. paradisiaca extract on DNA migration in peripheral blood leukocytes from Swiss albino mice on the comet assay. As expected, ENU used as positive control lead to some fragmentation and migration of peripheral blood leukocytes in the SCGE assay. Significant effects on DNA migration were found at the two higher M. paradisiaca extract concentrations tested. The $1000 \mathrm{mg} / \mathrm{kg}$ dose of the extract produced some DNA damage in the cells but this increase was not statistically significant. When cells were exposed to the test extract, most cells examined on slides were undamaged (class 0 ), few cells showed minor damage (class 1 ) and very few showed a large amount of damage (classes 2 and 3). Furthermore, there was a significant difference in DNA migration among the three extract concentrations tested (Table 1). 
Table 1. DNA migration in the comet assay for the assessment of genotoxicity of Musa paradisiaca extract in peripheral blood leukocytes (collected $24 \mathrm{~h}$ after the treatment) from female (F) and male (M) Swiss mice in vivo.

\begin{tabular}{|c|c|c|c|c|c|c|c|}
\hline \multirow[t]{2}{*}{ Treatment } & \multirow[t]{2}{*}{ Animals } & \multirow[t]{2}{*}{ Total $^{1}$} & \multicolumn{4}{|c|}{ Comet class } & \multirow[t]{2}{*}{ Scores } \\
\hline & & & 0 & 1 & 2 & 3 & \\
\hline \multirow[t]{7}{*}{ Control } & $\mathrm{F}_{1}$ & 3 & 97 & 3 & 0 & 0 & 3 \\
\hline & $\mathrm{F}_{2}$ & 3 & 97 & 3 & 0 & 0 & 3 \\
\hline & $\mathrm{F}_{3}$ & 1 & 99 & 1 & 0 & 0 & 1 \\
\hline & $\mathrm{M}_{1}$ & 5 & 95 & 5 & 0 & 0 & 5 \\
\hline & $\mathrm{M}_{2}$ & 2 & 98 & 2 & 0 & 0 & 2 \\
\hline & $\mathrm{M}_{3}^{2}$ & 4 & 96 & 4 & 0 & 0 & 4 \\
\hline & Mean \pm SD & $3.0 \pm 1.41$ & $97.0 \pm 1.41$ & $3.0 \pm 1.41$ & $0 \pm 0$ & $0 \pm 0$ & $3.0 \pm 1.41$ \\
\hline \multirow{7}{*}{$\begin{array}{l}\text { M. paradisiaca extract } \\
(1000 \mathrm{mg} / \mathrm{kg})\end{array}$} & $\mathrm{F}_{1}$ & 6 & 94 & 6 & 0 & 0 & 6 \\
\hline & $\mathrm{F}_{2}$ & 8 & 92 & 8 & 0 & 0 & 8 \\
\hline & $\mathrm{F}_{3}$ & 5 & 95 & 5 & 0 & 0 & 5 \\
\hline & $\mathrm{M}_{1}$ & 9 & 91 & 9 & 0 & 0 & 9 \\
\hline & $\mathrm{M}_{2}$ & 9 & 91 & 9 & 0 & 0 & 9 \\
\hline & $\mathrm{M}_{3}$ & 4 & 96 & 4 & 0 & 0 & 4 \\
\hline & Mean \pm SD & $6.83 \pm 2.13$ & $93.1 \pm 2.13$ & $6.83 \pm 2.13$ & $0 \pm 0$ & $0 \pm 0$ & $6.83 \pm 2.13$ \\
\hline \multirow{7}{*}{$\begin{array}{l}\text { M. paradisiaca extract } \\
(1500 \mathrm{mg} / \mathrm{kg})\end{array}$} & $\mathrm{F}_{1}$ & 19 & 81 & 10 & 6 & 3 & 31 \\
\hline & $\mathrm{F}_{2}$ & 20 & 80 & 10 & 5 & 5 & 35 \\
\hline & $\mathrm{F}_{3}$ & 12 & 88 & 7 & 3 & 2 & 19 \\
\hline & $\mathrm{M}_{1}$ & 14 & 86 & 7 & 7 & 0 & 21 \\
\hline & $\mathrm{M}_{2}$ & 16 & 84 & 7 & 5 & 4 & 29 \\
\hline & $\mathrm{M}_{3}^{2}$ & 32 & 68 & 21 & 10 & 1 & 44 \\
\hline & Mean $\pm \mathrm{SD}$ & $18.8 \pm 7.11^{* * *}$ & $81.1 \pm 7.11^{* * *}$ & $10.3 \pm 5.42 *$ & $6.0 \pm 2.36^{*}$ & $2.5 \pm 1.87$ & $29.8 \pm 9.2^{* *}$ \\
\hline \multirow{7}{*}{$\begin{array}{l}\text { M. paradisiaca extract } \\
(2000 \mathrm{mg} / \mathrm{kg})\end{array}$} & $\mathrm{F}_{1}$ & 35 & 65 & 22 & 8 & 5 & 53 \\
\hline & $\mathrm{F}_{2}$ & 20 & 80 & 17 & 1 & 2 & 25 \\
\hline & $\mathrm{F}_{3}$ & 35 & 65 & 11 & 13 & 11 & 70 \\
\hline & $\mathrm{M}_{1}$ & 26 & 74 & 14 & 5 & 7 & 65 \\
\hline & $\mathrm{M}_{2}$ & 32 & 68 & 19 & 10 & 3 & 48 \\
\hline & $\mathrm{M}_{3}$ & 25 & 75 & 13 & 5 & 7 & 64 \\
\hline & Mean \pm SD & $28.8 \pm 6.11 * * *$ & $71.1 \pm 6.11 * * *$ & $16.0 \pm 4.09 * * *$ & $7.0 \pm 4.24 *$ & $5.8 \pm 3.25$ & $54.1 \pm 16.4^{* * *}$ \\
\hline \multirow{7}{*}{$\begin{array}{l}\text { N-nitroso-N-ethylurea } \\
(50 \mathrm{mg} / \mathrm{kg})\end{array}$} & $\mathrm{F}_{1}$ & 93 & 7 & 14 & 25 & 54 & 226 \\
\hline & $\mathrm{F}_{2}$ & 79 & 21 & 18 & 23 & 38 & 178 \\
\hline & $\mathrm{F}_{3}^{2}$ & 80 & 20 & 8 & 37 & 35 & 187 \\
\hline & $\mathrm{M}_{1}^{3}$ & 82 & 18 & 11 & 31 & 40 & 193 \\
\hline & $\mathrm{M}_{2}$ & 81 & 19 & 19 & 33 & 29 & 172 \\
\hline & $\mathrm{M}_{3}^{2}$ & 83 & 17 & 11 & 31 & 41 & 196 \\
\hline & Mean \pm SD & $83.0 \pm 5.09^{* * *}$ & $17.0 \pm 5.09^{* * *}$ & $13.5 \pm 4.32^{* * *}$ & $30.0 \pm 5.1 * * *$ & $39.5 \pm 8.3^{* * *}$ & $192 \pm 18.9^{* * *}$ \\
\hline
\end{tabular}

${ }^{1}$ Total number of cells with damage (classes $\left.1+2+3\right)$.

* Significantly different from the negative control $(\mathrm{P}<0.05)$.

$* *$ Significantly different from the negative control $(\mathrm{P}<0.01)$.

$* * *$ Significantly different from the negative control $(\mathrm{P}<0.001)$.

To have a parameter of comparison with the SCGE assay, in the present study we also applied a micronucleus test. The most attractive features of this assay are the rapidity and ease with which in vivo genetic activity can be demonstrated and the knowledge that these events, being chromosomal in nature, are likely to be significant ones in terms of human risk (Salamone et al., 1980; Mavournin et al., 1990).

Table 2 shows the micronucleus test results obtained in female and male Swiss mice treated with M. paradisiaca extract: the number of micronucleated polychromatic erythro- 
cytes of each animal and means, for untreated controls and treated animals. The results obtained showed a statistically significant increase in the average number of micronucleated, polychromatic erythrocytes in the 3 doses tested of the plant extract. This table also shows the ratio between the average number of polychromatic erythrocytes with respect to normochromatic erythrocytes in 1000 randomly cells analyzed from each animal. The increased number of micronucleated cells was not associated with cytotoxicity because the polychromatic/normochromatic erythrocyte ratio was not significantly decreased at any doses tested.

Table 2. Number of micronucleated polychromatic erythrocytes (MNPCE) observed in the peripheral blood cells of female (F) and male (M) Swiss mice treated with a Musa paradisiaca extract, and respective controls.

\begin{tabular}{|c|c|c|c|c|c|c|c|c|c|}
\hline \multirow[t]{2}{*}{ Treatment } & \multirow{2}{*}{$\begin{array}{c}\text { Time of } \\
\text { blood collection }\end{array}$} & \multicolumn{6}{|c|}{ Number of MNPCE per animal } & \multirow{2}{*}{$\begin{array}{c}\text { MNPCE } \\
(\text { mean } \pm \mathrm{SD})\end{array}$} & \multirow{2}{*}{$\begin{array}{r}\mathrm{PCE} / \mathrm{NCE} \\
(\text { mean } \pm \mathrm{SD}\end{array}$} \\
\hline & & $\mathrm{F}_{1}$ & $\mathrm{~F}_{2}$ & $\mathrm{~F}_{3}$ & $\mathrm{M}_{1}$ & $\mathrm{M}_{2}$ & $\mathrm{M}_{3}$ & & \\
\hline \multirow{2}{*}{$\begin{array}{l}\text { Negative control } \\
\text { (water) }\end{array}$} & $48 \mathrm{~h}$ & 3 & 2 & 5 & 3 & 2 & 3 & $3.0 \pm 1.09$ & $2.62 \pm 0.59$ \\
\hline & $72 \mathrm{~h}$ & 3 & 4 & 1 & 3 & 3 & 6 & $3.33 \pm 1.63$ & $2.07 \pm 0.24$ \\
\hline \multirow{2}{*}{$\begin{array}{l}\text { Musa paradisiaca } \\
(1000 \mathrm{mg} / \mathrm{kg})\end{array}$} & $48 \mathrm{~h}$ & 6 & 9 & 7 & 4 & 8 & 8 & $7.0 \pm 1.78 * * *$ & $2.10 \pm 0.50$ \\
\hline & $72 \mathrm{~h}$ & 6 & 8 & 7 & 6 & 4 & 6 & $6.16 \pm 1.32 *$ & $1.97 \pm 0.46$ \\
\hline \multirow{2}{*}{$\begin{array}{l}\text { Musa paradisiaca } \\
(1500 \mathrm{mg} / \mathrm{kg})\end{array}$} & $48 \mathrm{~h}$ & 11 & 7 & 8 & 7 & 7 & 9 & $8.16 \pm 1.60^{* * *}$ & $3.17 \pm 0.90$ \\
\hline & $72 \mathrm{~h}$ & 6 & 7 & 7 & 7 & 9 & 6 & $7.0 \pm 1.09^{* *}$ & $2.27 \pm 1.03$ \\
\hline \multirow{2}{*}{$\begin{array}{l}\text { Musa paradisiaca } \\
(2000 \mathrm{mg} / \mathrm{kg})\end{array}$} & $48 \mathrm{~h}$ & 7 & 10 & 8 & 8 & 6 & 7 & $7.66 \pm 1.36^{* * *}$ & $1.62 \pm 0.17$ \\
\hline & $72 \mathrm{~h}$ & 9 & 9 & 7 & 8 & 7 & 11 & $8.5 \pm 1.51 * * *$ & $2.40 \pm 0.62$ \\
\hline Positive control & $48 \mathrm{~h}$ & 12 & 15 & 10 & 12 & 12 & 11 & $12.0 \pm 1.67^{* * *}$ & $1.98 \pm 0.78$ \\
\hline $\begin{array}{l}\text { N-nitroso-N-ethylurea } \\
(50 \mathrm{mg} / \mathrm{kg})\end{array}$ & $72 \mathrm{~h}$ & 11 & 9 & 12 & 10 & 11 & 12 & $10.83 \pm 1.16^{* * *}$ & $1.93 \pm 0.41$ \\
\hline
\end{tabular}

For each time (48 and $72 \mathrm{~h}$ ), 2000 cells were analyzed. $\mathrm{SD}=$ standard deviation; $\mathrm{PCE}=$ polychromatic erythrocytes; $\mathrm{NCE}=$ normochromatic erythrocytes.

"Significantly different from the negative control $(\mathrm{P}<0.05)$.

${ }^{* *}$ Significantly different from the negative control $(\mathrm{P}<0.01)$.

${ }^{* * *}$ Significantly different from the negative control $(\mathrm{P}<0.001)$.

The phytochemistry screen of $M$. paradisiaca extracts has shown the presence of several polysaccharides. The stalk of the rhizome (scape) of $M$. paradisiaca contains at least 4 different polysaccharide fractions. Its analysis indicated that the scape is essentially a solid state gel containing $\sim 1.5 \%$ polyphenols and $\sim 10 \%$ polysaccharides (D-Glc, L-Ara, D-Xyl, D-Glucan) with the rest being water $(\sim 88.5 \%)$ in association with minerals, potassium, silica, lignin, and polyphenolic pigments (Anjaneyalu et al., 1997). Methanol extracts of the fruits contain diarylheptanoid, 1,2-dihydro-1,2,3-trihydroxy-9-(4-methoxyphenyl)phenalene, hydroxyanigorufone, 2-(4-hydroxyphenyl)naphthalic anhydride and 1,7-bis(4-hydroxyphenyl)hepta-e(E),6(E)-dien-3-one (Jang et al., 2002). Mucilaginous exudates from the pseudo-stem contain uronic acid, neutral sugars, proteins, rhamnose, arabinose, xylose, mannose, galactose, glucose as well as other specific sugars (Mondal et al., 2001). The trace element concentrations of the fruit peels and trunks were described by Selema and Farago (1996); however, there are no data about M. paradisiaca fruit peel extract in the literature.

Many studies have shown positive results for the mutagenic action of plant extracts (Sánchez-Lamar et al., 2002; Zanoni et al., 2005). Studies such as ours indicate the importance 
of scientifically evaluating the security of the products used in popular medicine, especially those derived from plants. The mutagenic effect of the $M$. paradisiaca fruit peel extract on peripheral blood cells of Swiss mice was studied for the first time in the present article. The results indicated that this crude extract presented a mutagenic effect on blood cells. As fruit peel extract from $M$. paradisiaca is commonly included in folk medicine used by numerous individuals, it seems advisable to moderate its use, and to develop other mutagenic tests to finally establish the health risk for humans.

\section{ACKNOWLEDGMENTS}

We would like to thank the Brazilian agencies CNPq (\#306544/2006-7), FAPESP (\#2006/57514-2) and FAPEMIG (Rede Mineira de Ensaios Toxicológicos e Farmacológicos de Produtos Terapêuticos, EDT - 1879/02) for financial support, and Lucimara Maria da Silva for technical assistance.

\section{REFERENCES}

Anjaneyalu YV, Jagadish RL and Raju TS (1997). Polysaccharide components from the scape of Musa paradisiaca: main structural features of water-soluble polysaccharide component. Glycoconj. J. 14: 507-512.

Barrett B (1994). Medicinal plants of Nicaragua's Atlantic Coast. Econ. Bot. 48: 8-20.

Borges MH, Alves DL, Raslan DS, Pilo-Veloso D, et al. (2005). Neutralizing properties of Musa paradisiaca L. (Musaceae) juice on phospholipase A2, myotoxic, hemorrhagic and lethal activities of Crotalidae venoms. J. Ethnopharmacol. 98: 21-29.

Coe F and Anderson GJ (1999). Ethnobotany of the Sumu (Ulwa) of southeastern Nicaragua and comparisons with Miskitu plant lore. Econ. Bot. 53: 363-383.

Goel RK, Sairam K and Rao CV (2001). Role of gastric antioxidant and anti-Helicobacter pylori activities in antiulcerogenic activity of plantain banana (Musa sapientum var. paradisiaca). Indian J. Exp. Biol. 39: 719-722.

Hartmann A and Speit G (1997). The contribution of cytotoxicity to DNA - effects in the single cell gel test (comet assay). Toxicol. Lett. 90: 183-188.

Houghton PJ and Skari K (1992). The effect of Indian plants used against snakebite on blood clotting. J. Pharm. Pharmacol. 44: 1054-1060.

Jang DS, Park EJ, Hawthorne ME, Vigo JS, et al. (2002). Constituents of Musa x paradisiaca cultivar with the potential to induce the phase II enzyme, quinone reductase. J. Agric. Food Chem. 50: 6330-6334.

Klaude M, Eriksson S, Nygren J and Ahnstrom G (1996). The comet assay: mechanisms and technical considerations. Mutat. Res. 363: 89-96.

Krishnan K and Vijayalakshmi NR (2005). Alterations in lipids \& lipid peroxidation in rats fed with flavonoid rich fraction of banana (Musa paradisiaca) from high background radiation area. Indian J. Med. Res. 122: 540-546.

Lewis DA, Fields WN and Shaw GP (1999). A natural flavonoid present in unripe plantain banana pulp (Musa sapientum L. var. paradisiaca) protects the gastric mucosa from aspirin-induced erosions. J. Ethnopharmacol. 65: 283-288.

Mavournin KH, Blakey DH, Cimino MC, Salamone MF, et al. (1990). The in vivo micronucleus assay in mammalian bone marrow and peripheral blood. A report of the U.S. Environmental Protection Agency Gene-Tox Program. Mutat. Res. 239: 29-80.

Mondal SK, Ray B, Thakur S and Ghosal PK (2001). Isolation, purification and some structural features of the mucilaginous exudate from Musa paradisiaca. Fitoterapia 72: 263-271.

Ojewole JA and Adewunmi CO (2003). Hypoglycemic effect of methanolic extract of Musa paradisiaca (Musaceae) green fruits in normal and diabetic mice. Methods Find. Exp. Clin. Pharmacol. 25: 453-456.

Prasad KV, Bharathi K and Srinivasan KK (1993). Evaluation of Musa (Paradisiaca Linn. cultivar) - "Puttubale" stem juice for antilithiatic activity in albino rats. Indian J. Physiol. Pharmacol. 37: 337-341.

Rates SM (2001). Plants as source of drugs. Toxicon 39: 603-613.

Salamone M, Heddle J, Stuart E and Katz M (1980). Towards an improved micronucleus test: studies on 3 model agents, mitomycin C, cyclophosphamide and dimethylbenzanthracene. Mutat. Res. 74: 347-356. 
Sánchez-Lamar A, Fuentes JL, Fonseca G, Capiro N, et al. (2002). Assessment of the potential genotoxic risk of Phyllantus orbicularis HBK aqueous extract using in vitro and in vivo assays. Toxicol. Lett. 136: 87-96.

Sasaki YF, Tsuda S, Izumiyama F and Nishidate E (1997). Detection of chemically induced DNA lesions in multiple mouse organs (liver, lung, spleen, kidney, and bone marrow) using the alkaline single cell gel electrophoresis (Comet) assay. Mutat. Res. 388: 33-44.

Selema MD and Farago ME (1996). Trace element concentrations in the fruit peels and trunks of Musa paradisiaca. Phytochemistry 42: 1523-1525.

Singh NP, McCoy MT, Tice RR and Schneider EL (1988). A simple technique for quantitation of low levels of DNA damage in individual cells. Exp. Cell Res. 175: 184-191.

Sokal RR and Rohlf FJ (1995). The Principles and Practice of Statistics in Biology Research. Biometry. W.H. Freeman, San Francisco, 175-205, 404-486.

Speit G and Hartmann A (1999). The comet assay (single-cell gel test). In: Methods in Molecular Biology (Henderson DS, ed.). Humana Press Inc., Totowa, 203-212.

Stover RH and Simmonds NW (1987). Bananas (Tropical Agriculture Series, 3rd edn.). Longman Scientific and Technical, Essex, Harlow, 86-101.

Tewari HK, Marwaha SS and Rupal K (1986). Ethanol from banana peels. Agric. Wastes 16: 135-146.

Zanoni FD, Andrade SF, Bastos JK and Maistro EL (2005). Clastogenicity of the Austroplenckia populnea (Celastraceae) bark wood extract in Wistar rat bone marrow cells. Cytologia 70: 303-308. 